\title{
Bilim ve Sanat Merkezlerinde Yürütülen Proje Çalışmalarına İlişkin Öğrenci Görüşlerinin Değerlendirilmesi
}

\author{
Oğuzhan Nacaroğlu ${ }^{1}$, Mehmet Arslan ${ }^{2}$ \\ ${ }^{1}$ Eğitim Bilimleri Enstitüsü, Erciyes Üniversitesi, Kayseri, Türkiye \\ ${ }^{2}$ Milli Eğitim Bakanlığı, Malatya, Türkiye
}

Sorumlu Yazar: Oğuzhan Nacaroğlu, onacaroglu44@gmail.com

Makale Türü: Araştırma Makalesi

Kaynak Gösterimi: Nacaroğlu, O., \& Arslan, M. (2019). Bilim ve sanat merkezlerinde yürütülen proje çalışmalarına ilişkin öğrenci görüşlerinin değerlendirilmesi. Eğitimde Kuram ve Uygulama, 15(3), 220-236. doi: 10.17244/eku.581804

\section{Evaluation of Students' Opinions on the Project Studies in Science and Art Centers}

\author{
Oğuzhan Nacaroğlu ${ }^{1}$, Mehmet Arslan ${ }^{2}$ \\ ${ }^{1}$ Graduate School of Educational Sciences, Erciyes University, Kayseri, Turkey \\ ${ }^{2}$ Ministry of National Education, Malatya, Turkey
}

Corresponding Author: Oğuzhan Nacaroğlu, onacaroglu44@gmail.com

Article Type: Research Article

To Cite This Article: Nacaroğlu, O., \& Arslan, M. (2019). Bilim ve sanat merkezlerinde yürütülen proje çalışmalarına ilişkin öğrenci görüşlerinin değerlendirilmesi. Eğitimde Kuram ve Uygulama, 15(3), 220-236. doi: 10.17244/eku.581804 


\title{
Bilim ve Sanat Merkezlerinde Yürütülen Proje Çalışmalarına İlişkin Öğrenci Görüşlerinin Değerlendirilmesi
}

\author{
Oğuzhan Nacaroğlu ${ }^{1}$, Mehmet Arslan ${ }^{2}$ \\ ${ }^{1}$ Eğitim Bilimleri Enstitüsü, Erciyes Üniversitesi, Kayseri, Türkiye \\ ORCID: http://orcid.org/0000-0001-8516-9152 \\ ${ }^{2}$ Milli Ĕ̆itim Bakanlı̆̆l, Malatya, Türkiye \\ ORCID: http://orcid.org/0000-0003-0519-373X
}

\begin{tabular}{|c|c|}
\hline Öz & Makale Bilgisi \\
\hline 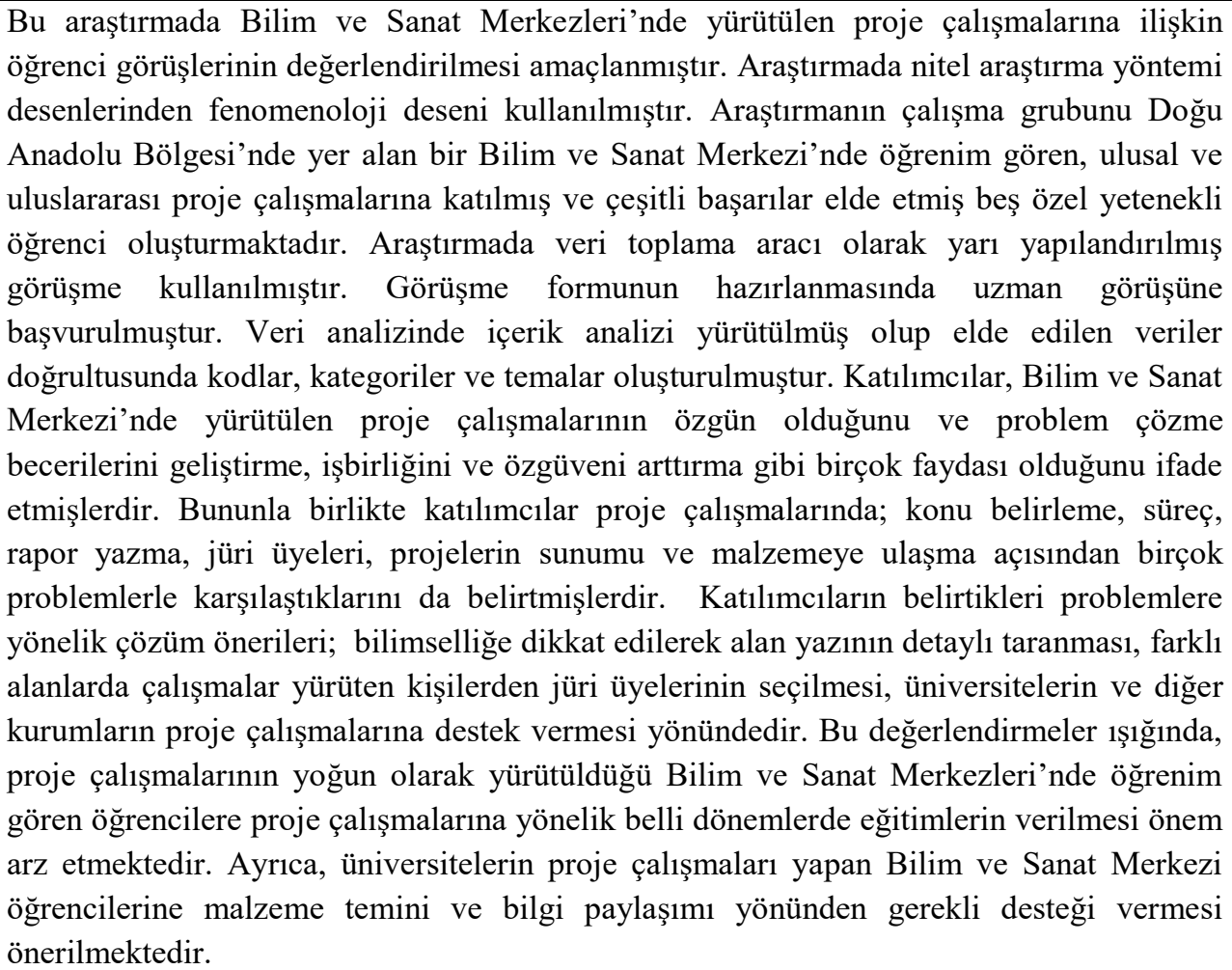 & $\begin{array}{l}\text { Anahtar Kelimeler: Bilim ve } \\
\text { Sanat Merkezi, Fenomenoloji, } \\
\text { Özel yetenekli öğrenci, Proje } \\
\text { çalışmaları } \\
\text { Makale Geçmişi: } \\
\text { Geliş: } 24 \text { Haziran } 2019 \\
\text { Düzeltme: } 13 \text { Eylül } 2019 \\
\text { Kabul: } 16 \text { Eylül } 2019 \\
\text { Makale Türü: Araştırma } \\
\text { Makalesi }\end{array}$ \\
\hline
\end{tabular}




\section{Evaluation of Students' Opinions on the Project Studies in Science and Art Centers}

\begin{tabular}{|c|c|}
\hline Abstract & Article Info \\
\hline $\begin{array}{l}\text { In this research, the aim was to evaluate students' opinions about the project work } \\
\text { carried out in Science and Art Centers. Phenomenology design, a qualitative } \\
\text { research design, was used in the research. The research group consisted of five } \\
\text { gifted students studying at a Science and Art Center in the Eastern Anatolia } \\
\text { Region and participating in national and international project studies. In the } \\
\text { research, a semi-structured interview was used as the data collection tool. Expert } \\
\text { opinion was sought in the preparation of the interview form. Content analysis was } \\
\text { carried out in the data analysis and codes, categories and themes were created in } \\
\text { line with the data obtained. The participants stated that the project work carried } \\
\text { out at the Science and Art Center are original and have many benefits such as } \\
\text { fostering problem solving skills, cooperation and self-confidence. In addition, } \\
\text { participants in the project work also stated that they faced many problems in } \\
\text { terms of subject determination, process, report writing, jury members, } \\
\text { presentation of projects and access to materials. In order to solve the problems, } \\
\text { the participants suggested that the literature should be scanned in detail paying } \\
\text { attention to scientific aspects, and the jury members should be selected from } \\
\text { persons carrying out studies in different fields. It was also recommended that } \\
\text { universities and other institutions should support the project work. In the light of } \\
\text { these evaluations, it is important to provide training on project studies to the } \\
\text { students studying in Science and Art Centers where project activities are carried } \\
\text { out intensively. In addition, it is recommended that universities provide the } \\
\text { necessary support to Science and Art Center students who carry out project } \\
\text { studies, in terms of material supplies and information sharing. }\end{array}$ & $\begin{array}{l}\text { Keywords: Gifted student, } \\
\text { Phenomenology, Project } \\
\text { studies, Science and Art } \\
\text { Center } \\
\text { Article History: } \\
\text { Received: } 24 \text { June } 2019 \\
\text { Revised: } 13 \text { September } 2019 \\
\text { Accepted: } 16 \text { September } 2019 \\
\text { Article Type: Research } \\
\text { Article }\end{array}$ \\
\hline
\end{tabular}




\section{Giriş}

Toplumların görev aldığı işlerde bilinçli, istekli, çalışkan, problem çözme becerisi yüksek bireylere sahip olması (Özarslan, 2019), geleceklerini sağlam temeller üzerinde inşa etmesi ve refah seviyelerinin yükselmesi noktasında büyük bir fırsattır. Bu bireyler, toplumlar için çok büyük bir kazanç olup bu bireylerin en önemli kısmını yaşıtlarına göre genel zeka gelişimi, yaratıcı çözüm üretme becerileri ve motivasyon düzeyleri yüksek olan (Renzulli, 1986) özel yetenekli öğrenciler oluşturmaktadır (Levent, 2014). Özel yetenekli öğrenciler, yaşadıkları her dönemde en önemli insan kaynağını oluştururlar (Orbay, Gökdere, Tereci, \& Aydın, 2010) ve yaşıtlarına göre birçok farklı özelliklere sahiptirler.

Özel yetenekli öğrenciler; problemlere farklı açıdan bakarak eleştirel düşünebilirler, karışık problemleri çözmekten hoşlanabilirler (Erdoğan, 2018), ilgi duydukları alanlarda azimli bir şekilde çalışabilirler, zor olan görevleri tercih edebilirler (Abu, 2018), güçlü sezgileri sayesinde problemlere pratik çözümler bulabilirler (Johnsen, 2004). Bununla birlikte zamanlarının büyük bir kısmını projelerle uğraşarak geçirebilirler (Stuart \& Beste, 2011). Bu öğrenciler, sahip oldukları yetenekleri doğrultusunda yetiştirildiğinde toplumların gelecekte çok daha iyi bir konumda olmasına büyük katkı sağlayacaktır (Demirhan, 2018). Bundan dolayı özel yetenekli öğrencilerin farkına varan toplumlar, bu öğrencilere gerekli iyileştirmelere giderek akranlarından farklı bir öğretim programının uygulanması gerekliliğini düşünmüşler ve kurumsal bazda çalışmalar yürütmüşlerdir (Clark, 2013). Ülkemizde de özel yetenekli öğrencilerin eğitimlerine yönelik açılan ve günümüzde de faaliyetlerine devam eden kurumların başında Bilim ve Sanat Merkezleri (BİLSEM) gelmektedir.

BİLSEM'ler, özel yetenekli öğrencilerin örgün eğitimlerini aksatmayacak şekilde bireysel yeteneklerinin farkında olmalarını, yeteneklerini geliştirmelerini sağlamayı amaç edinmiş ve bu öğrencilerin bilimsel yaratıcılıklarını destekleyen bağımsız özel eğitim kurumlarıdır (MEB, 2017). Sanat ve zihinsel yetenek açısından özel yetenekli olduğu düşünülen çocuklar BILLSEM'lere kayıt yaptırabilmek için iki aşama içeren sınava tabi tutulurlar (Sarıtaş, Şahin, \& Çatalbaş, 2019). Bu sınavlarda başarı gösteren öğrenciler; uyum, destek eğitimi, bireysel yetenekleri fark ettirme (BYF), özel yetenekleri geliştirme (ÖYG) ve proje üretimi programlarını içeren beş aşamalı bir eğitimden geçerek (Sezginsoy, 2007), alanında uzman ve deneyimli öğretmenlerin rehberliğinde eğitimlerini tamamlarlar. BİLSEM'lerde önem verilen alanlardan birisi de proje üretimi ve proje çalışmalarıdır (Tortop, 2013).

BİLSEM'lerde yürütülen proje çalışmalarının öğrencilere birçok faydası bulunmaktadır. Zamanlarının birçoğunu problemlere çözüm bulma ve proje çalışmalarına ayıran özel yetenekli öğrencilerin BİLSEM'lerde bunu daha sistemik bir şekilde yapmaları önemli görülmektedir. Çünkü proje çalışmaları öğrencilerin; yaparak yaşayarak öğrenmelerine firsat verir (Gültekin, 2009), bağımsız çalışabilme yeteneklerini geliştirir, gerçek yaşam sorunlarına ilgilerini arttırır (Liu, Lou, Shih, Meng, \& Lee, 2010). Ayrıca proje çalışmaları, öğrencilere bilimsel araştırma yapabilme becerisi de kazandırır (Raghavan, Coken-Regev, \& Strobel, 2001). Bu bakımdan özel yetenekli öğrencilerin eğitimlerinde önemli bir yere sahip olan proje çalışmaları (Powers, 2008), BİLSEM gibi kurumlarda yaygın bir şekilde kullanılan zenginleştirme stratejilerinden de birisidir (Johnsen \& Goree, 2009). Bu kurumlarda yürütülen proje çalışmalarının birçok faydası olup danışman öğretmenler tarafından sıklıkla kullanılmasına rağmen, proje çalışmalarında birçok sorunla karşı karşıya kalınmaktadır (Çetin \& Şengezer, 2013).

Proje çalışmalarında görev alan öğrenciler; malzeme ve veri toplama aracına ulaşmada, proje raporu yazım ve sunum aşamasında, proje fikrinin oluşturulmasında, görev paylaşımında ve proje çalışmaları süresince birçok problemlerle karşılaşmaktadır (Mills, 2003; Ocak \& Ulusoy, 2010). Özellikle proje çalışmalarına önem veren BİLSEM'lerde öğrenim gören özel yetenekli öğrencilerin proje çalışmaları süresince karşılaştıkları problemlerin tespit edilmesi gerekmektedir (Ayvacı \& Çoruhlu, 2010; Sarı \& Öğülmüş, 2014). Çünkü BİLSEM'lerde danışman öğretmenler rehberliğinde yürütülen proje çalışmalarının fikir üretme aşamasından projenin sunum ve raporlaştırma sürecine kadar dikkatli bir şekilde planlanması, bu projelerin amacına ulaşması noktasında önemlidir (Ülger, 2011). Proje çalışmaları öğrencilerin ihtiyaçları ve beklentilerine göre organize edilmediğinde ise, proje çalışmaları istenilen amaca ulaşamaz ve bunun sonucunda öğrencilerin bu programa yönelik ilgi ve isteklerinin azalıp (Özarslan \& Çetin, 2015), ülkelerin önemli insan kaynağını oluşturan bu öğrencilerden yeterli verim alınamaz. Bu kapsamda BILLSEM'lere devam edip proje çalışmalarında bizzat görev alan özel yetenekli öğrencilerin bu kurumlarda yürütülen proje çalışmalarına ilişkin görüşlerinin belirlenmesi önem arz etmektedir.

\section{Araştırmanın Amacı}


Bu çalışmada BİLSEM'lerde yürütülen proje çalışmalarına ilişkin öğrencilerin görüşlerini incelemek hedeflenmiştir. Yürütülen bu çalışmayla; BİLSEM'lerde yürütülen projelerin öğrencilere katkıları, öğrencilerin proje çalışmalarında karşılaştıkları problemler ve bu problemlere yönelik çözüm önerileri, öğrencilerin proje çalışmalarından beklentileri proje çalışmalarında görev almış öğrencilerin görüşleri neticesinde derinlemesine incelenmiştir. Bu çalışma sonucu elde edilen bulguların; proje çalışması yapmak isteyecek öğrencilere, proje danışmanlığı yapan öğretmenlere ve bu alanda çalışma yapacak olan araştırmacılara yardımcı olacağ “Bilim ve Sanat Merkezleri’nde yürütülen proje çalışmalarına ilişkin öğrenci görüşleri nasıldır?” sorusuna cevap aranmıştır.

\section{Yöntem}

\section{Araştırmanın Amacı}

$\mathrm{Bu}$ çalışmada, nitel araştırma yöntemi desenlerinden fenomenoloji (olgu-bilim) deseni kullanılmıştır. Fenomenoloji, özü görüleme yöntemi olmakla birlikte, günlük hayatta karşılaşabileceğimiz, ancak derinlemesine ve ayrıntılı bilgi sahibi olmadığımız olguları araştıran (Creswell, 2013) ve kişilerin görüşlerinden anlam çıkarmayı hedefleyen nitel araştırma yöntemi desenidir (Kaya, 2019; Yıldırım \& Şimşek, 2013). Bu çalışmada da BİLSEM'lerde proje çalışmalarına katılmış öğrencilerin, proje çalışmalarına ilişkin görüşlerini derinlemesine incelenmesi amaçlanmıştır. $\mathrm{Bu}$ amaç doğrultusunda çalışmada fenomenoloji deseni tercih edilmiştir.

\section{Çalışma Grubu}

$\mathrm{Bu}$ araştırmanın çalı̧̧ma grubunu, 2018-2019 eğitim öğretim döneminde Doğu Anadolu Bölgesi'nde yer alan bir BİLSEM'de öğrenim gören ve proje çalışmalarına katılmış beş öğrenci oluşturmaktadır. Araştırmanın çalışma grubunun belirlenmesinde amaçlı örnekleme yöntemlerinden ölçüt örnekleme yöntemi tercih edilmiştir. Ölçüt örneklemede, örneklem birimleri belli özellikleri bünyesinde barındıran kişiler, nesneler ve olaylardan oluşur (Büyüköztürk, Kılıç-Çakmak, Akgün, Karadeniz, \& Demirel, 2012). Bu kapsamda çalışma grubunu oluşturan kişiler; BİLSEM'de öğrenimine devam eden, proje çalışmalarına aktif bir şekilde katılmış ve yapılan ulusal ve uluslararası proje çalışmalarında belli derecelerde ödül kazanmış bireyler tercih edildiğinden çalışma grubunun belirlenmesinde ölçüt örnekleme yöntemi tercih edilmiştir. Katılımcılara gizlilik kapsamında farklı isimler verilmiştir. Araştırmada yer alan katılımcılara yönelik demografik bilgiler Tablo 1'de verilmiştir:

Tablo 1.Katılımcilara yönelik demografik bilgiler

\begin{tabular}{ccc}
\hline Katılımcılar & Cinsiyet & Proje çalışması yaptığı alan \\
\hline Ali & Erkek & Matematik, Biyoloji, Değerler eğitimi \\
Fuat & Erkek & Fizik \\
Mert & Erkek & Biyoloji \\
Zeynep & Kadın & Matematik \\
Metin & Erkek & Kimya, Biyoloji \\
\hline
\end{tabular}

Tablo 1 incelendiğinde, katılımcıların farklı alanlarda projeler yaptıkları görülmektedir. Ayrıca görüşme esnasında öğrencilerin tamamı yürüttükleri proje çalışmalarının ulusal ve uluslararası proje yarışmalarında başarı gösterdiklerini ifade etmiştir.

\section{Veri Toplama Aracı}

$\mathrm{Bu}$ araştırmada, veri toplama aracı olarak yarı yapılandırılmış görüşme kullanılmıştır. Yarı yapılandırılmış görüşme formunun hazırlanmasında öncelikle alan yazın taraması yapılmış (Ay, 2013; Kı1ıç \& Özel, 2015; Özarslan \& Çetin, 2018; Özarslan, 2015; Öztuna-Kaplan \& Diker-Coşkun, 2012; Tortop, 2013) ve 12 maddeden oluşan yarı yapılandırılmış görüşme formu oluşturulmuştur. Görüşme formunda yer alan bazı sorulara proje tabanlı öğrenme üzerinde akademik çalışmalar yapan iki uzmanın görüşleri doğrultusunda sondalar eklenmiştir. Bu kapsamda 6., 7. ve 8. sorulara sondalar eklenmiştir. Örneğin, "Proje çalışmalarında kimlerin nasıl desteği oldu?" sorusuna "Rehber öğretmen açısından değerlendiriniz.", "Aileniz açısından değerlendiriniz." ve "Arkadaşlarınız açısından değerlendiriniz." sondaları eklenmiştir. Ayrıca alanında uzman iki fen eğitimcisinin, BİLSEM'lerde görev alan ve proje çalışmalarına rehberlik etmiş üç danışman öğretmenin ve bir Türkçe öğretmeninin görüşlerine başvurularak görüşme formunun yeterlilik ve anlaşırlık açısından geçerliliği sağlanmaya çalışılmıştır. 


\section{Geçerlik ve Güvenirlik Çalışması}

Çalışmanın geçerlik ve güvenirliğini tehdit eden faktörleri kontrol altına almak için bir dizi çalışma yapılmıştır (Yıldırım \& Şimşek, 2013). Yürütülen çalışmalar Tablo 2'de verilmiştir:

Tablo 2. Yapılan çalışmada alınan geçerlik ve güvenirlik önlemleri

\begin{tabular}{ccc}
\hline & Önerilen Önlemeler & Alınan Önlemler \\
\hline \multirow{4}{*}{ Geçerlik } & Veri toplama aracı ve sürecinin açıklanması & + \\
& Veri analiz sürecinin açıklanması & + \\
& Çalışma grubunun özelliklerinin açıklanması & + \\
& Katılımc gönüllüllügünün sağlanması & + \\
& Geçerlik ve güvenirlik önlemlerinin açıklanması & + \\
Güvenirlikşmenin sessiz bir ortamda yapılması & + \\
& Uzman görüşünün alınması & + \\
\hline
\end{tabular}

Tablo 2 incelendiğinde geçerliği ve güvenirliği sağlamak için yapılmış çalışmalar görülmektedir. Bu kapsamda görüşme formunun hazırlanmasında uzmanların görüşlerine başvurulmuş (İç geçerlik) ve görüşme esnasında sessiz bir ortam sağlanmıştır (İç güvenirlik). Ses kayıt cihazı kullanılarak kaydedilen görüşmeler metne aktarılarak katılımcılara ulaştırılmıştır (Katılımcı teyidi). Çalışmada kullanılan yöntemin seçilme nedeni, çalışma grubu, çalışmanın uygulanma süreci, veri toplama aracı ve analiz süreci detaylı bir şekilde açıklanmıştır (Dış geçerlik). Ayrıca bulgular kısmında katılımcıların görüşleri doğrudan aktarılmış olup (İç güvenirlik), veriler bulgular kısmında tartışılmıştır (Dış güvenirlik).

\section{Verilerin Analizi}

$\mathrm{Bu}$ araştırmada verilerin analizinde içerik analizi kullanılmıştır. İçerik analizi, kodların, kategori altında toplanarak yorumlanması (Yıldırım \& Şimşek, 2013), kategorilerin sentezlenmesiyle de temaların oluşturulmasını ve bu şekilde olay, olgu ve duruma yönelik özün ortaya konmasını hedefler (Giorgi, 2009). Bu çalışmada da verilerin analizinde; katılımcı görüşlerinin metne aktarılması, metin ile ses kaydının teyit edilmesi, verilerin kodlanması, kodlar dikkate alınarak kategori ve temaların oluşturulması, temaların amaç doğrultusunda düzenlenerek bulgular kısmında tartışılması şeklinde aşamalar izlenmiştir (Corbin \& Strauss, 2007). Bulgular kısmında katılımcıların görüşleri kodların altında takma isimleri ile verilmiş ve katılımcıların görüşme formunda yer alan sorulara verdikleri cevaplar doğrultusunda anlam birimleri oluşturulmasıyla elde edilen kodlar, kategoriler ve temalar bulgular kısmında detaylı bir şekilde incelenmiştir.

\section{Proje Çalışmalarının Yararları}

\section{Bulgular}

Katılımcılara "BİLSEM'de yer aldığınız proje çalışmalarının size nasıl katkısı olmuştur? Açıklayınız." sorusu yöneltilmiş ve öğrencilerin görev aldıkları proje çalışmalarının kendilerine sağladıkları yararları detaylı bir şekilde ifade etmeleri istenmiştir. Katılımcıların görüşleri doğrultusunda "Proje çalışmalarının yararlarl" teması belirlenmiş olup, bu tema altında ortaya çıkan kategori ve kodlar Tablo 3 'te verilmiştir:

Tablo 3. Proje çalışmalarının yararları

\begin{tabular}{ccccccc}
\hline Kategori & Kod & Ali & Fuat & Mert & Zeynep & Metin \\
\hline Karar verme yeteneğimi geliştirdi & & $\mathrm{X}$ & & & \\
Kroje & Kendime güvenimi arttırdı & & & $\mathrm{X}$ & $\mathrm{X}$ & \\
Çalışmaları & $\begin{array}{c}\text { Bilimsel araştırma yeteneği kazandırdı } \\
\text { Problem çözme becerisi kazandırdı }\end{array}$ & $\mathrm{X}$ & & & $\mathrm{X}$ & \\
& İşbirliğini artırdı & & & & $\mathrm{X}$ \\
\hline
\end{tabular}

Tablo 3 incelendiğinde katılımcılardan Ali, proje çalışmalarının problem çözme becerisini ve grup arkadaşları işbirliği içinde çalışma alışkanlığı kazanmasına yardımcı olduğunu ifade etmiştir. Bu duruma yönelik görüşünü “...öncelikle özgün düşünme ve problem çözme yeteneklerimi geliştirdiğini düşünüyorum. Çünkü yaptığınız projelerde kendinize ait konu bulmanız lazım. Ve bu kendinize ait konuyu kendinize ait bir yöntemle çözmeniz lazım... Aynı zamanda takım arkadaşlarımın yanı sıra öğretmenlerimizle de beraber bir koordinasyon içinde olduğumuz için başkaları ile beraber 
ortaklaşa nasıl bir çalışma yapabileceğimizi daha iyi öğrenmiş olduk.” şeklinde belirtmiştir. Aynı şekilde Fuat, proje çalışmalarının karar verme yeteneğini geliştirdiğini "BILSEM'de yer aldiğım proje çalışmaları benim karar verme yeteneğime ve mental gelişimime katkı sağladığını düşünüyorum." şeklinde ifade ederken diğer katılımcıların görüşleri ise şöyledir:

Illk önce kendime olan güvenim arttı. Orda başka insanlarla tanıştım. Çevrem genişledi. Ailemin bana baklş açısı değişti. Öğretmenlerimin Bilim Sanat ve okulumun. Güzel oldu. Bana bir sürü katkısı oldu yani (Mert),

BILLSEM'de yer aldı̆̆ım proje çalışmaları bana öncelikle bilimsel alanda araştırma yapma ve bunu kendince yorumlama katklsı olmuştur. Bunun dışında özgüven, sunum yapma, bir şeyler oluşturma katkıları da olmuştur (Zeynep),

Yani günlük hayatımda karşılaştığım problemlere çözüm fikirleri üretiyorum ve bu şekilde yeni proje fikirleri oluşturuyorum. Sonuç olarak da tabii ki ülkemize katkı sağlamış oluyoruz (Metin).

\section{BILLSEM'lerin Proje Yapma Yeterliliğine Etkisi}

Katılımcılara "BILLSEM'de verilen eğitimlerin, yapılan etkinliklerin proje oluşturma yeterliliğine etkisi nedir? Açıklayınız." sorusu yöneltilmiş ve "Yeterli değilse çözüm öneriniz nelerdir?" sondası ile BİLSEM'de verilen eğitim ve etkinlikleri öğrencilerin proje yapma yeterliliğine etkisi öğrencilerin görüşlerine göre detaylı incelenmeye çalışılmıştır. Katılımcıların görüşleri doğrultusunda "BILLSEM'in proje yapma yeterliliğine etkisi" teması belirlenmiş olup, bu tema altında ortaya çıkan kategori ve kodlar Tablo 4'te verilmiştir:

Tablo 4. BILLSEM'in proje yapma yeterliliğine etkisi

\begin{tabular}{ccccccc}
\hline Kategori & Kod & Ali & Fuat & Mert & Zeynep & Metin \\
\hline \multirow{2}{*}{ BİLSEM proje üretmede } & Yeterli & $\mathrm{X}$ & $\mathrm{X}$ & $\mathrm{X}$ & & $\mathrm{X}$ \\
& Az yeterli & & & & $\mathrm{X}$ & \\
\hline
\end{tabular}

Tablo 4 incelendiğinde Zeynep, BİLSEM'de verilen eğitimin tüm dersler noktasında proje yapma yeterliliğine etkisinin aynı olmadığını ifade etmiştir. Buna yönelik görüşünü ise "Bütün dersler için dersek Fizik konusunda fazla popüler fizik olarak ilgilenildiğini düşünmüyorum ama matematik ve diğer alanlarda yeterli olduğunu düşünüyorum." şeklinde ifade etmiştir. Diğer katılımcılar BİLSEM'de, proje yapma yeterliliğine etki bakımından yeterli çalışmaların olduğunu ifade etmişler ve katılımcıların buna yönelik görüşleri ise şöyledir:

Burada özgün fikirlerimiz çok önemsendi. Ayrıca Matematik dersinde de sorulan problemlere özgün cevapların çok daha değer kazandığını gördüm. O yüzden kendime ait özgün çözümler oluşturmaya çalıştım kimi zaman. Böylece özgün düşünme yeteneğimin geliştiğini düşünüyorum (Ali),

Zaten bu etkinliklerin amaçları öğrencilere proje yapmaya alıştırmak ve proje mantığını öğrencilere yerleştirmek ve bence bu bağlamda başarılı olduklarını düşünüyorum bu etkinliklerin (Fuat),

Bayağı etkisi var. Çünkü biz yıllardır buradayız. Bize burada çok şeyler. Biz daha çok küçükken mikroskop kullandık, teleskop kullandık. Bir sürü etkinlikler, deneyler yaptık. Bunlar tabi bizim proje yapmamız için hocalar bize önayak oldular. Bizi bayă̆g etkilediler yani. Yeterli etkisi var (Mert),

Şöyle Bilim ve Sanat Merkezlerinde özellikle fen dalları içerisindeki ĕgitimler ağırlıkl olarak laboratuvarla yürütülen eğitimler oldukları için sizler başta proje fikrinizi belirledikten sonra o projeyi hayata geçirme testlerini yapma, deneylerini yapma kısımları hiç zor gelmiyor (Metin).

\section{Proje Çalışmalarının Amacına Ulaşması}

Katılımcılara "Yer aldığınız proje çalışmalarının amacına ulaştığını düşünüyor musunuz? (Özgün ürün ortaya koyma açısından değerlendiriniz.) " sorusu yöneltilmiş olup BİLSEM'lerde yürütülen proje çalışmalarının özgün ürün ortaya koyma noktasında yeterli olup olmadığı incelenmek istenmiştir. Katılımcıların görüşleri doğrultusunda "Proje çalışmalarının amacına ulaşması ” teması belirlenmiş olup, bu tema altında ortaya çıkan kategori ve kodlar Tablo 5 'te verilmiştir:

Tablo 5. Proje çalışmalarının amacına ulaşması

\begin{tabular}{ccccccc}
\hline Kategori & Kod & Ali & Fuat & Mert & Zeynep & Metin \\
\hline Özgünlük Açısından & Yeterli & $X$ & $X$ & $X$ & $X$ & $X$ \\
\hline
\end{tabular}


Tablo 5 incelendiğinde katılımcıların tamamı BİLSEM'de yürütülen proje çalışmalarının amacına ulaştığını ve özgün ürün ortaya koyma noktasında yeterli olduklarını ifade etmişlerdir. Bu duruma yönelik örneğin Mert "Bence evet öyle. Ben öyle düşünüyorum. Çünkü yer aldığımız proje, yaptı̆̆ımız şeyler çok özgün projelerdi. Olmayan literatürde. Biz bunları yaptık. Amacımıza ulaştı̆̆ımızı düşünüyoruz. Bilinmeyen bir şey ortaya çıktı." şeklinde görüşünü dile getirmiştir. Diğer katılımcıların bu konu hakkında görüşleri ise şöyledir:

Yer aldı̆̆ım proje çalışmalarının amacına ulaştı̆̆ını düşünüyorum. Çünkü yaptığım projelerin çoğu tamamen bana ait fikirlere dayanıyordu. Öğretmenlerime ait. Böylece geliştirilerek oluşturulan fikirler olduğu için bu fikirler tamamen bizden çıktı̆̆ için özgün tabi özgün ürün ortaya koymada çok önemli olduğunu düşünüyorum (Ali),

Zaten bir projeyi yarı̧̧malara sokmak için özgün olması gerekiyor. Bu sebepten ötürü evet. Özgünlük açısından da yeterli (Fuat),

Proje çalışmamın amacına ulaştığını düşünüyorum. Özgün bir proje olduğunu ve kriptoloji ve matematiği birleştirdiğini düşünüyorum. Bunun dışında geliştirilebileceğini düşünüyorum. Yeterli (Zeynep),

Bu kapsamlardan bakttğımızda proje ciddi anlamda özgün bir projeydi. Çünkü hem daha önce denenmemis materyallerin denenmesi hem de temel konuda denenmiş konular var. Benzer konular var. Ancak materyal olarak benim çalışmam için materyaller düzgündü ve sonuçlar da sağllklı ve özgün bir sonuç elde etmiştik biz kendi çalı̧̧mamızda (Metin).

\section{Proje Çalışmalarına Kişilerin Desteği}

Katılımcılara "Proje çalışmalarında kimlerin nasıl desteği oldu?" sorusu yöneltilmiş olup "Danışman öğretmeniniz açısından değerlendiriniz.", "Aileniz açısından değerlendiriniz.", "Arkadaşlarınız açısından değerlendiriniz." sondaları ile katılımcıların proje çalışmalarını destekleyen kişi ve kurumlara yönelik görüşleri detaylı incelenmek istenmiştir. Katılımcıların görüşleri doğrultusunda "Proje çalışmalarına kişilerin desteği”" teması belirlenmiş olup, bu tema altında ortaya çıkan kategori ve kodlar Tablo 6'da verilmiştir:

Tablo 6. Proje çalışmalarına kişilerin desteği

\begin{tabular}{ccccccc}
\hline Kategori & Kod & Ali & Fuat & Mert & Zeynep & Metin \\
Danışman & Proje sürecinin tüm aşamasında & $\mathrm{X}$ & $\mathrm{X}$ & $\mathrm{X}$ & $\mathrm{X}$ & $\mathrm{X}$ \\
öğretmenler & yardımcı oluyorlar & $\mathrm{X}$ & $\mathrm{X}$ & $\mathrm{X}$ & $\mathrm{X}$ & $\mathrm{X}$ \\
Aile & Proje çalışmalarına destek oluyorlar & $\mathrm{X}$ & $\mathrm{X}$ & $\mathrm{X}$ & $\mathrm{X}$ & $\mathrm{X}$ \\
Arkadaşlar & Motive ediyorlar & $\mathrm{X}$ & $\mathrm{C}$
\end{tabular}

Katılımcıların tamamı proje çalışmalarında danışman öğretmenlerin proje konusu belirlemekten projenin sunum ve rapor aşamasına kadar birçok süreçte yardımcı olduklarını ifade etmişlerdir. Buna yönelik görüşleri ise şöyledir:

...hani bir proje yaparken danışman ögretmeninizin konuyu nerden ilerleyeceğinizi veya işlemi nerden devam ettireceğinizi dair soruna dair her şeyi soruyorsunuz. Ve danışman öğretmenin burada yardımı çok etkili. Bu yüzdende danışman öğretmenlerim bana gayet yardımcı olmuşlardı. Hepsine tek tek teşekkür ediyorum (Ali),

Danışman açısından olarak danışmanların hem proje raporunu yazmayı ögrencilere öğretmesi konusunda hem de proje sırasında her konuda bize danışmanlık yapması için yapması yönünden çok başarılı olduğunu düşünüyorum (Fuat),

Danışman öğretmenimiz, hocamı bize çok destek oldu. Neler yapabileceğimiz konusunda, her aşamasında, rapor aşamasında, deney aşamalarında bizim yanımızda ve arkamıdda oldu, hep yanımızdaydı yani. Büyük desteği var (Mert),

... araştırma yaparken de bize sunduğu işte olanaklar olsun, işte üniversitedeki hocalarla konuşma imkanları olsun, danışman ögretmenimizin bize büyük bir desteği olduğunu, katkısı olduğunu söyleyebilirim (Zeynep),

Katılımcılara proje çalışmalarına ailelerinin katkısı sorulduğunda katılımcıların tamamı proje çalışmalarında ailelerinin her konuda yardımcı olduklarını ifade etmişledir. Örneğin bu duruma yönelik görüşünü Fuat "Ailem bu konuda her zaman bana destek oluyor. Bence de olması gereken bu. Doğru yapıyorlar.” şeklinde ifade ederken Mert "Annem babam çok destek oldu. Yaparsın oğlum git yani. Hiçbir zaman demediler yani boş bir şey yapma falan demediler. Dediler yap çok iyi işte. Öyle güzel destekleri oldu." şeklinde görüşünü belirtmiştir. Aynı şekilde proje çalışmalarına derslerine göre daha fazla yoğunlaşan Metin bu durumda bile ailesinden destek gördüğünü "Benim projedeki başarım, buradan benim hedeflerim, proje hedeflerim ders hedeflerimden daha öncelikli idi. Bu yüzden bir miktar derslerimi savsakladım. Ancak ailem buna rağmen benim arkamda durdular." şeklinde ifade etmiştir. 
Katılımcıların tamamı proje çalışmaları esnasında arkadaşlarının destek olup motive ettiklerini hatta proje çalışmalarından dolayı aksayan okul derslerinde arkadaşlarının dersleri tekrar etme noktasında yardımcı olduklarını (Ali) ifade etmişlerdir. Bu duruma yönelik katılımcı görüşleri şu şekildedir:

...Ben hani proje yarı̧̧malarına gittiğim zaman çoğu derslere giremedim. Burada arkadaşlarımdan eksik kaldığım dersleri almam gerekiyordu. Bu konuda bana çok yardımcı oldular. Ayrıca Bilim Sanatta ve yaptığım projede ortak olarak hani proje ortağı olarak arkadaşlarımda bana projemi geliştirmede ve onun beraber yaptığımız için projeyi geliştirmede çok yardımcı olduğunu düşünüyorum (Ali),

Onlar da ellerinden geldiğince bana yardımcı oluyorlar. Özellikle zamanım olmadığında beraber rapor yazıyoruz. O konuda çok yardımcı oluyorlar (Fuat),

Şaşırdılar. Ama onlarda benim kadar mutlu oldular. Sonuçta arkadaşlarım arasında popülaritem arttı diyebilirim. Yaptı̆̆ım şey güzel oldu diyebilirim (Mert),

Arkadaşlarımın da aynı şekilde manevi desteği oldu (Zeynep),

\section{Proje Çalışmalarında Karşılaşılan Problemler}

Katılımcılara "Proje çalışmaları sırasında bir problemle karşılaştınız mı?" sorusu yöneltilmiş ve "Konu belirleme açısından değerlendiriniz.", "Danışman öğretmeniniz açısından değerlendiriniz.", "Proje süreci açısından değerlendiriniz.", "Projenin raporlaştırılması açısından değerlendiriniz.", "Jüri üyeleri açısından değerlendiriniz.", "Sunum açısından değerlendiriniz." ve "Malzemeye ve veri toplama aracına ulaşma açısından değerlendiriniz." sondaları ile katılımcıların proje çalışması süresi boyunca tüm alanlarda karşılaştıkları problemler detaylı bir şekilde incelenmiştir. Katılımcıların görüşleri doğrultusunda "Proje çalışmalarında karşılaşılan problemler" teması belirlenmiş olup, bu tema altında ortaya çıkan kategori ve kodlar Tablo 7'de verilmiştir:

Tablo 7. Proje çalışmalarında karşılaşılan problemler

\begin{tabular}{|c|c|c|c|c|c|c|}
\hline Kategori & Kod & Ali & Fuat & Mert & Zeynep & Metin \\
\hline Konu açısından & $\begin{array}{c}\text { Zaman problemi oluyor } \\
\text { Konu belirlemede sorun yaşıyorum } \\
\text { Sorun yaşamadım }\end{array}$ & $X$ & $\mathrm{X}$ & $X$ & $\mathrm{X}$ & $\mathrm{X}$ \\
\hline $\begin{array}{l}\text { Danışma öğretmen } \\
\text { açısından }\end{array}$ & Problem yaşamadım & $\mathrm{X}$ & $\mathrm{X}$ & $\mathrm{X}$ & $\mathrm{X}$ & $\mathrm{X}$ \\
\hline $\begin{array}{l}\text { Proje süreci } \\
\text { aç1sından }\end{array}$ & $\begin{array}{c}\text { Süre kısa olabiliyor } \\
\text { Yorucu } \\
\text { Bilgi toplama sorun yaşadım } \\
\text { Sorun olmadı }\end{array}$ & $\mathrm{X}$ & $\mathrm{X}$ & $\mathrm{X}$ & $\mathrm{X}$ & $\mathrm{X}$ \\
\hline $\begin{array}{l}\text { Raporlaştırma } \\
\text { açısından }\end{array}$ & $\begin{array}{l}\text { Problem yaşamadım } \\
\text { Problem yaşadım }\end{array}$ & $\mathrm{X}$ & $X$ & $\mathrm{X}$ & $X$ & $\mathrm{X}$ \\
\hline $\begin{array}{l}\text { Jüri üyeleri } \\
\text { açısından }\end{array}$ & $\begin{array}{l}\text { Problem yaşamadım } \\
\text { Problem yaşadım }\end{array}$ & $\mathrm{X}$ & $\mathrm{X}$ & $\mathrm{X}$ & $\mathrm{X}$ & $\mathrm{X}$ \\
\hline Sunum açısından & $\begin{array}{l}\text { Problem yaşamadım } \\
\text { Problem yaşadım }\end{array}$ & $\mathrm{X}$ & $\mathrm{X}$ & $\mathrm{X}$ & $X$ & $\mathrm{X}$ \\
\hline $\begin{array}{l}\text { Malzeme ve veri } \\
\text { toplama aracına } \\
\text { ulaşma açısından }\end{array}$ & $\begin{array}{l}\text { Problem yaşamadım } \\
\text { Problem yaşadım }\end{array}$ & $\mathrm{X}$ & $\mathrm{X}$ & $\mathrm{X}$ & $\mathrm{X}$ & $\mathrm{X}$ \\
\hline
\end{tabular}

Tablo 7 incelendiğinde Ali proje konusu belirlemede zaman problemi yaşadığını ifade etmiştir. Bu duruma yönelik görüşünü "Ben geçen sene yani bu sene yaptığım projede Matematik projesinde konuyu çok geç buldum. O yüzdende çok hızl bir şekilde projeyi yapmak zorunda kaldım." şeklinde belirtmiştir. Zeynep ise proje konusu belirlemede sorun yaşadığını "ilk olarak konumuz farklıydı. Daha sonra konuyu araştırdıkça farklı konulara geçis yaptık. Problem olarak karşılaştı̆̆ınız şey tıkanma noktaları oldu. İşte yeni bir konu bulamayınca, eskisine de devam edemeyince tıkandık." şeklinde ifade etmiştir. Diğer katılımcılar konu açısından bir problem yaşamadıklarını ifade etmişlerdir. Örneğin bu duruma yönelik Metin "Aslında problem değil ama zorlayıcı olması biraz dikkat çekiyor. Çünkü sizin yaptığınız çalışmanın hem yaşınıza uygun olması gerekiyor, maddi açıdan mümkün olması gerekiyor. Bilimsel açıdan mümkün olması gerekiyor...” şeklinde görüşünü belirtmiştir.

Katılımcıların tamamı danışman öğretmenlerinden proje süreci boyunca hep destek gördüklerini ve herhangi bir sorun yaşamadıklarını ifade etmişlerdir. Bu duruma yönelik görüşünü Mert "Danışman öğretmen yani bize hiç şey 
olmadı, köstek olmadı. Hep yardımcı oldu. Hiçbir zaman problem yaşamadık. Danışman öğretmen açısından." şeklinde ifade ederken Ali "Danışman ögretmenin açısından herhangi bir problem yaşamadım. Çok teşekkür ediyorum bütün danışman ögretmenlerime." şeklinde belirtmiştir.

Proje süreci açısından Ali sürenin kısa olduğunu "Proje süreci bu sene yaptı̆̆ım projeden ilerleyecek olursak çok sıklştım. Hani u özellikle raporu yetiştirme konusunda. O yüzden projeni bazı yerleri hatta nerdeyse ögretmenlerle konuştuğum zaman yarım kalmıştı nerdeyse." şeklinde belirtirken, yorucu bir süreç olduğunu, Fuat "Proje süreci her zaman yorucu oluyor. Ĕger bir projeye başlayacaklarsa yorulmaya alışmalılar diyorum." şeklinde ifade etmiş̧ir. Aynı şekilde proje sürecinde projeyle ilgili bilgi toplamada sorun yaşayan Zeynep bu duruma yönelik görüşünü "Genel olarak daha fazla bilgi edinme konusunda sorun yaşadık." şeklinde ifade ederken proje sürecinde bir problem yaşamadığını söyleyen Mert "Proje süreci çok eğlenceli geçti. Severek yaptık, birlikte zamanımızı buna verdik. Boş zamanımız geçmedi, dolu dolu geçti. Güzeldi yani.” şeklinde görüşünü belirtmiştir.

Projelerin raporlaştırılması açısından Ali ve Mert bir problem yaşamadıklarını ifade ederken; Fuat, Zeynep ve Metin problem yaşadıklarını ifade etmişlerdir. Bu duruma yönelik Fuat "Evet burada ögrencilerin bitiş haline çok dikkat etmesi gerekiyor. Çünkü rapor aslında projelerin en önemli kısımlarından biri ve yazım aşamasında zorluk çektik." şeklinde görüşünü belirtirken Metin "En önemli kısmı zaten rapor kısmıydı. Yazarken zorlandım ama hocam sağ olsun yardımcı oldu." şeklinde belirtmiştir.

Projelerin jürilere sunumu esnasında katılımcıların büyük bir çoğunluğu sorun yaşadıklarını ifade etmişlerdir. Bu duruma yönelik Ali görüşünü “...jüriler birazcık hani çok soğuk, fazla soğuk ve katı davranmışlardı.” şeklinde ifade ederken, Zeynep jüri üyelerinin alanları dışı projelere dikkat etmediğini "Jüri üyeleri açısından problemler yaşadık tabi. Hocaların ilgilendiği alanlar olsun, bizim projemiz ile ilgili olmayınca çeşitli sıkıntılar yaşadık." şeklinde ifade etmiştir. Fuat jüri üyelerinin zamanları olmadığı için projesini dinlemediklerini "Bakın şimdi burada çok önemli bir şey var. Jüri üyeleri ile çok problem yaşadım ben. Özellikle de geçen hafta yok birkaç hafta önce bir proje yarışmasına katıldım. Orda da jüri üyelerinin zamanı olmadı̆̆ için sunum yaptırmadılar. Ve bu bence hiç doğru bir şey değildi. Ve ben bir daha o proje yarışmasına katılmayacă̆ım.” şeklinde ifade ederken Metin jürilerin projeleri az sürede dinlediklerini "Proje sergisinde 15-20 dk süremiz vardl. Hem tanttım hem de soru cevap kısımları için geçerli olan bir süre bu. Orada o süreye sıkıştırmaya çalıştı̆̆ım zaman biraz yoruyor. Jüriler dinlemeyip sürenin bittiğini ifade ediyorlar.” şeklinde belirtmiştir. Bununla birlikte Mert katıldığı proje yarışmasında jüri üyelerinin yeterli donamına sahip olduğunu "Bölgedeki jürilerden iyi idi. Bizim jürimiz bayă̆ı iyi idi." şeklinde belirterek katıldığı proje yarışmalarında jüriler açısından bir problem yaşamadığını ifade etmiştir.

Projelerin sunumu açısından Ali, Fuat ve Mert bir sorun yaşamadıklarını ifade etmişlerdir. Bu duruma yönelik örneğin Ali "Sunum açısından bir problem yaşamadım. Sadece slaytları hazırlarken hani biraz ince eleyip sık dokumak gerekiyor. Onun dışında herhangi bir problemim yok." şeklinde ifade etmiştir. Bununla birlikte katılımcılardan Zeynep ve Metin problem yaşadıklarını ifade etmişlerdir. Bu duruma yönelik görüşünü Zeynep "Yaptı̆̆ımı sunumlar diksiyon açısından eksik olduğu için pek bir harika değildi doğruyu söylemek gerekirse." şeklinde ifade ederken Metin yurt dişında katıldığı yarışmada sunum esnasında yabancı dil sorunu yaşadığını “...birinci olarak ana diliniz dışında bir dille sunum yapmamız gerekiyor ki ben her ne kadar proje üretimi için canımı dişime takarak çalı̧̧mış olsam da açık söylemem gerekiyor ki proje sunumu konusunda bir ihmalkarlık oluşmuştu o dönemde." şeklinde ifade etmiştir.

Katılımcılardan Ali ve Mert proje sürecinde malzeme ve veri toplama aracına ulaşma noktasında bir problem yaşamadıklarını ifade etmişlerdir. Bu duruma yönelik Ali "O konuda çok bir hani problemle karşılaşmadım." şeklinde görüşünü belirtmiştir. Bununla birlikte Fuat, Zeynep ve Metin problem yaşadıklarını ifade etmişlerdir. Çalıştığı alanla ilgili bilgi toplamada sorun yaşadığını belirten Zeynep "Bilgilenme konusunda etrafimızda bilgili insanlar yoktu ve buna ulaşmak zor oldu. Kodlama konusunda bilgilenemedik daha çok. Bunun için üniversiteye gittik. Çeşitli hocalardan bilgi istedik. Ama iletişimimiz çok iyi olmadiğı için hocalarla biraz sorun yaşadık." şeklinde görüşünü belirtirken, projesi ile ilgili malzemeyi yurt dişından istemek zorunda kalan Metin "O konuda ciddi sıkıntımız vardı. Şöyle ki bizim malzemelerimiz İsviçre'den geliyordu. Ísviçre'den gelen malzemelerin siparişini veriyorsunuz, gümrüğe takıldl, gümrükten geçti işte farklı bir konu üzerinden alışveriş yapmanız gerekiyor. Derken ana malzeme ulaşmak ciddi anlamda zorlayıcı idi.” şeklinde görüşünü belirtmiştir. 


\section{Çözüm Önerileri}

Katılımcılara "Proje çalışmaları sürecinde karşılaştığınız problemlere yönelik çözüm öneriniz nelerdir" sorusu yöneltilmiştir. Katılımcıların görüşleri doğrultusunda "Çözüm önerileri” teması belirlenmiş olup, bu tema altında ortaya çıkan kategori ve kodlar Tablo 8'de verilmiştir:

Tablo 8. Çözüm önerileri

\begin{tabular}{|c|c|c|c|c|c|c|}
\hline Kategori & Kod & Ali & Fuat & Mert & Zeynep & Metin \\
\hline \multirow[t]{2}{*}{ Konu açısından } & Alan yazın detaylı taranmalı & $\mathrm{X}$ & $\mathrm{X}$ & & $\mathrm{X}$ & \\
\hline & Bilimselliğe dikkat edilmeli & & & $\mathrm{X}$ & & $X$ \\
\hline \multirow{2}{*}{$\begin{array}{l}\text { Raporlaştırma } \\
\text { açısından }\end{array}$} & Bilimsel makaleler takip edilmeli & & $\mathrm{X}$ & & & \\
\hline & Dil bilgisi eğitimi önemli & & & & $\mathrm{X}$ & \\
\hline Jüri üyeleri & $\begin{array}{l}\text { Sunum günü başka bir işle } \\
\text { ilgilenmemeli } \\
\text { Farklı konularla ilgilenen kişiler } \\
\text { olmalı }\end{array}$ & & $\mathrm{X}$ & & $X$ & \\
\hline \multirow[t]{2}{*}{ Sunum açısından } & $\begin{array}{c}\text { Diksiyon ve hitabet eğitimine önem } \\
\text { verilmeli }\end{array}$ & & & & $\mathrm{X}$ & \\
\hline & Hazırlık yapılmalı & & & $\mathrm{X}$ & & $\mathrm{X}$ \\
\hline $\begin{array}{l}\text { Malzeme ve veri } \\
\text { toplama aracına } \\
\text { ulaşma açısından }\end{array}$ & $\begin{array}{l}\text { Üniversite ve diğer kurumlar destek } \\
\text { olmalı }\end{array}$ & & $\mathrm{X}$ & & $\mathrm{X}$ & $\mathrm{X}$ \\
\hline
\end{tabular}

Katılımcılardan Ali, Fuat ve Zeynep proje konusunu belirlerken alan yazının detaylı taranması gerektiğini ifade etmişlerdir. Bu kapsamda Fuat "Proje yapanlar bol bol makale okusunlar. Ingilizcelerini geliştirsinler." şeklinde öneri sunarken, Zeynep "Çözüm önerimiz daha çok makale okumak işte daha fazla insanlarla sohbet ederek yeni fikirler üretmek olabilir." şeklinde görüşünü belirtmiştir. Bununla birlikte Mert ve Metin proje konusu belirlenirken bilimselliğin önemli olduğunu ifade etmişlerdir. Bu kapsamda Metin görüşünü "Bilimsel açıdan mümkün olması gerekiyor ve hani uygulanabilir olmasl, ekonomiye katkısl, çevreye etkisi. Bunların hepsini göz önünde bulundurarak bir şey seçmeniz gerekiyor." şeklinde ifade etmiştir.

Projelerin raporlaştırılması açısından nasıl olduğuna yönelik bilimsel makalelerin takibini önemseyen Fuat görüşünü "Evet. Bilimsel makaleleri okuyun. Çünkü bilimsel makalelerde aslında bizim rapor dediğimiz şey. Onları okudukça nasıl olacağını ögreniyorsunuz zaten kendiniz." şeklinde ifade ederken; dil bilgisi eğitimine dikkate çeken Zeynep “...projenin raporlaştırılmasında daha çok Türkçe ve Edebiyat hocalarına danışarak kurduğumuz cümleleri düzelttirdik. Diksiyon olsun geliştirdik, raporlaştırdık falan. Burada dil bilgisi eğitimi çok önemli.” şeklinde görüşünü ifade etmiştir.

Projelerin değerlendirilmesi sürecinde jüri üyelerinin proje sunumlarına önem vermesi gerektiğini ve o gün başka bir işe zaman ayırmamaları gerektiğini ifade eden Fuat görüşünü “...Jüri üyelerinin o günü tamamen boşaltmaları önemli." şeklinde ifade ederken, jüri üyelerinin farklı konu alanına ilgi duyan ve bilgisi olan kişiler olması gerektiğini ifade eden Zeynep görüşünü "Jüri üyelerinin çeşitti konularla ilgilenen kişilerden seçilmesi gerektiğini düşünüyorum. Tek bir konuya bağlı olarak değil de.” şeklinde ifade etmiştir.

Projelerin sunumunun etkili olabilmesi için diksiyon ve hitabete önem verilmesi gerektiğini ifade eden Zeynep “...bizim daha fazla diksiyon ve hitabet konusunda çalışarak bu sorunu aşabileceğimizi düşünüyorum.” şeklinde görüşünü ifade ederken, Mert ve Metin sunuma ciddi bir şekilde hazırlık yapılması gerektiğini ifade etmişlerdir. Bu kapsamda örneğin Metin “...bol hazırlıkla sunumlara gitmek daha uygun olacaktır.” şeklinde görüşünü belirtmiştir.

Katılımcılardan Fuat, Zeynep ve Metin proje sürecinde veri toplama aracına ve malzemeye ulaşma noktasında üniversitelerin ve diğer kurum ve kuruluşların destek olmaları gerektiğini ifade etmişlerdir. Bu kapsamda örneğin Zeynep "Bu sorun da üniversitelerin, üniversitedeki hocaların biraz daha ilgili ve daha zaman aytrabilecek şekilde olması ile halledilebilir. ” şeklinde görüşünü belirtmiştir. 


\section{Sonuç, Tartışma ve Öneriler}

$\mathrm{Bu}$ araştırmada BILLSEM'lerde yürütülen proje çalışmalarına ilişkin öğrenci görüşlerinin değerlendirilmesi amaçlanmış olup BİLSEM'de öğrenim gören ve proje çalışmalarına katılmış beş özel yetenekli öğrenciyle çalışma yürütülmüştür. Özel yetenekli öğrencilere görev aldıkları proje çalışmalarının yararları sorulduğunda proje çalışmalarının; karar verme yeteneğini geliştirdiğini, özgüveni arttırarak bilimsel araştırma yeteneğini kazandırdığını ve problem çözme becerisi ile işbirliğini arttırdığına yönelik görüşler öne sürmüşlerdir (Tablo 3). Elde edilen bu sonuç birçok çalışma ile benzerlik göstermektedir (İdin \& Özdemir-Şimşek, 2016; Lam, Cheng, \& Choy, 2010; Mioduser \& Betzer, 2007; Summers \& Dickinson, 2012). Örneğin İdin ve Özdemir (2016), yaptıkları çalışmada öğrenciler; proje çalışmalarının ders başarılarına olumlu katkı yaptığını, iletişimi arttırdığını, problem çözme becerilerini geliştirdiğini, derslere karşı olumlu tutum geliştirmelerine yardımcı olduğunu ifade etmişlerdir. Proje çalışmaları; öğrencilerin problem çözme ve eleştirel düşünme becerilerini geliştir ve öğrenciler arasındaki işbirliğini arttırarak etkili iletişim becerileri kazandırır (Chandrasekaran, Stojcevski, Littlefair, \& Joordens, 2012; Hart, 2019). Ayrıca proje çalışmaları, öğrencilerin çeşitli eğitim faaliyetlerinde anlama düzeylerini geliştiren ve bunu test eden etkili bir öğretim aracıdır (Cappelleri \& Vitoroulis, 2013; Rajan, Gopanna, \& Thomas, 2019). Buradan hareketle özel yetenekli öğrencilerin proje çalışmalarının belirtilen faydalarına dikkat çekmeleri, proje çalışmalarının yararlarına karşı farkındalıklarının fazla olduğunu desteklemektedir.

BİLSEM'de yapılan faaliyetlerin proje yapma yeterliliğine etkisi sorulduğunda katılımcıların çoğu yeterli düzeyde olduğunu ifade etmişlerdir (Tablo 4). BİLSEM'lerde proje üretimi ve yönetimine büyük önem verilmekte olup proje programında öğrenim gören özel yetenekli öğrenciler, danışman öğretmenlerin rehberliğinde istedikleri ve ilgi duydukları alanlarda projeler gerçekleştirmektedirler (MEB, 2015). BİLSEM'lerde proje çalışmalarının yoğun bir şekilde kullanılmasının altında yatan sebep (Gökdere \& Ayvacı, 2004) öğrenciye sağladığı kazanımlardır (Özarslan, Çetin, \& Yıldırım, 2017). Bu kapsamda öğrencilerin BİLSEM'in proje yapma konusunda yeterli olduğunu ifade etmeleri, proje çalışmalarının amacına ulaşması noktasında başarılı olduğunu desteklemektedir. Aynı zamanda BİLSEM'de yürütülen proje çalışmalarının amacına ulaşma ve özgün ürün ortaya koyma noktasında yeterli olup olmadıkları sorulduğunda katılımcıların tamamı yeterli olduğunu ifade etmişlerdir (Tablo 5). Proje çalışmaları yapan özel yetenekli öğrenciler ortaya koydukları ürünlerin özgün olmasını (Baykoç, 2014) ve bu şekilde insanlığa faydalı olmayı isterler. Dolayısıyla BİLSEM'de yürütülen projelerin öğrenciler tarafından özgün olduğunun ifade edilmesi BİLSEM'in işleyişi açısından olumlu bir sonuç olarak karşımıza çıkmaktadır.

BİLSEM'de yürütülen proje çalışmalarına danışman öğretmenlerin, ailelerin ve arkadaşların birçok açıdan destek oldukları katılımcıların tamamı tarafından ifade edilmiştir (Tablo 6). Bu kurumlarda yürütülen proje çalışmalarının sağlıklı bir şekilde yürütülebilmesi için başta projeye rehberlik eden öğretmenlerin ve diğer kişilerin destek olması önemlidir (Özarslan vd., 2017). Örneğin danışman öğretmenlerin; öğrencilerine özgüven duygusu kazandırması, sabırlı, samimi ve motive edici davranış sergilemeleri ve proje çalışmalarında yeterli bilgi ve donanıma sahip olmaları proje çalışmalarının daha sağlıklı bir şekilde ilerlemesi noktasında değerlidir (Tischler \& Vialle, 2009). $\mathrm{Bu}$ kapsamda da özel yetenekli öğrenciler; danışman öğretmenlerin projenin tüm sürecinde destek olduklarını ve ailelerinin ve arkadaşlarının proje çalışmaları süresince motive edici davranış sergilediklerini ifade etmeleri önemli bir sonuçtur.

Katılımcıların bir kısmı proje konusunu belirlemede sorun yaşadıklarını ifade etmişlerdir (Tablo 7). Proje konusu belirleme noktasında problem yaşayan katılımcılar konu belirlemede zaman sorunu yaşadıklarını söylemişlerdir. Öğrencilerin güncel dünya problemlerine somut çözümler üretebilmeleri için öncelikle problemin tanımlanması ve konu içeriğinin oluşturulması önemlidir. Bu noktada özellikle danışman öğretmenlerin öğrencilerin proje fikri bulma ve proje konusunun genel çerçevesini oluşturmasında gerekli desteği göstermeleri önem arz etmektedir (Aydın \& Çepni, 2011). Katılımcıların tamamının danışman öğretmenler açısından bir problem yaşamadıklarını ifade etmeleri elde edilen önemli bir sonuçtur. Bununla birlikte katılımcıların çoğu proje çalışmaları süresince sorun yaşadıklarını ifade etmişlerdir (Tablo 7). Bu konuda katılımcılar, proje sürecinin kısa olduğunu, yorucu ve bilgi toplama açısından sorunlar yaşadıklarını söylemişlerdir. Proje çalışmalarının sağlam temellere oturması için alan yazının iyi taranıp konu ile ilgili detaylı bilgilerin toplanması gerekmektedir (Baki \& Bütüner, 2009). Aynı şekilde proje çalışmaları yorucu ve yoğun bir çalışma sürecini de içermekte olup doğru proje fikri belirleyememe, zamanı etkili kullanamama gibi birçok sorun ortaya çıkabilmektedir (Çetin \& Şengezer, 2013). Bu yüzden özel yetenekli öğrencilerin proje sürecinde karşılaştıkları problemlerin dikkate alınması gerekmektedir. Aynı 
şekilde proje sürecinde projenin raporlaştırılması da önemli bir basamaktır. Bazı katılımcıların proje raporu yazmada da sorun yaşadıklarını ifade ettikleri görülmektedir. Elde edilen bu sonucun dikkate alınması önem arz etmektedir. Katılımcıların çoğu katıldıkları proje yarışmalarında jüri üyeleri açısından sorun yaşadıklarını ifade etmişlerdir (Tablo 7). Bu probleme yönelik ise katılımcılar, sunum esnasında jüri üyelerinin çalışmalarını dinlemediklerini ve alanları dışı projelere önem vermediklerini ifade ettikleri görülmektedir. Projelerin tamamlanması sürecinde, proje raporun oluşturulması ve projeyi anlatan sözlü ve poster sunumlarının yapılması gerekmektedir (Bell, 2010). Buradan hareketle jüri üyelerinin hal ve hareketleri önemli olup katılımcılar bu noktada çalışma ve ilgi alanı geniş kişilerden jüri üyelerinin seçilmesini, jüri üyelerinin proje günü sadece proje sunumlarına yoğunlaşmalarını önermişlerdir (Tablo $8)$.

Katılımcıların çoğu proje çalışmaları sırasında veri toplama aracına ulaşma ve malzeme temini noktasında sorun yaşadıklarını ifade etmişlerdir (Tablo 8). Özellikle ürün ve araştırma projelerinde malzemeye ulaşma kolaylığının sağlanması gerekmektedir. Çünkü tasarım, model veya simülasyon içeren proje çalışmalarında istenilen malzemelerin temini projenin amacına ulaşmasında önemli bir etkendir. Çünkü proje çalışmaları sırasında malzeme temininde yaşanan problemler, öğrencilerin ve danışman öğretmenlerin motivasyonlarını olumsuz bir şekilde etkilemektedir. Bu kapsamda katılımcılar üniversite ve diğer kurumların bu konuda yardımcı olmaları gerektiğini ifade etmişlerdir (Tablo 8). Buradan hareketle başarılı ve özgün projelerin ortaya çıkabilmesi için farklı materyallerin kullanılması gerekmekte, bunun için de okul idarelerinin, üniversitelerin ve diğer kurumların bu noktada projeleri desteklemesi önemlidir (İdin \& Özdemir-Şimşek, 2016). Tüm bu değerlendirmeler 1şığında BİLSEM’lerdeki proje çalışmalarının başarılı ve etkili bir şekilde yürütülebilmesi için aşağıda ifade edilen önerilerde bulunulmuştur:

- BILSEM'lerde öğrenim gören özel yetenekli öğrencilerin daha sağlıklı proje çalışmaları yürütebilmeleri için desteklenmesi ve bu kurumlarda proje çalışmalarına daha fazla önem verilmesi önerilmektedir. Belli dönemlerde BILSEM'lerde öğrenim gören öğrencilere ve öğretmenlere proje çalışmalarına yönelik eğitimlerin verilmesi önerilmektedir.

- Proje çalışmalarına BİLSEM'ler ve üniversiteler arasında yapılan ortak çalışmalar ile destek verilmesi önerilmektedir.

- Öncelikle öğrencilerin ilgi alanları belirlenerek doğru proje alanı için yönlendirilmeleri ve ilgili danışman öğretmenlerle buluşturulmaları gerekmektedir.

- Öğrenciler proje yapmaya teşvik edilmelidir. Bu amaçla öğrenciler alanlarında başarılar elde etmiş bilim insanlarıyla buluşturulmalıdır.

- Proje yarışmalarına katılıp başarı elde edemeyen öğrencilere gereken rehberlik desteği sağlanarak eksikleri belirlenmeli ve yeni projeler hazırlamalarına zemin oluşturulmalıdır. Bununla ilgili olarak proje yarışmalarında başarı elde edemeyen öğrencilerle yapılacak olan çalışmaların alan yazına katkı sağlayacağı düşünülmektedir.

- BİLSEM'lerde tüm alanlarda yapılan etkinlikler, BİLSEM öğrencilerinin kendilerine ait proje fikirleri oluşturmaları hedefine uygun olarak hazırlanmalıdır.

- BİLSEM'lerde öğrencilerden gelecek tüm fikirler öğretmenler tarafindan titizlikle incelenmeli ve değerlendirilmelidir. Bu fikirlerden özgün olanları işlenmeli ve projelere dönüştürülmelidir.

- Uzun soluklu ve yorucu proje sürecine dahil olan BILLSEM öğrencilerinin ailelerine ve BİLSEM ile beraber devam ettikleri okullarındaki idareci ve ders öğretmenlerine gerekli bilgilendirmeler yapılmalıdır.

- Jüri üyelerinin oluşturulmasında branşlar içinde farklı alanlarda çalışan bilim insanları tercih edilmelidir.

- Proje öğrencilerine sunumlarının daha etkili olabilmesi için diksiyon ve hitabet konusunda eğitimler verilmelidir.

- Uluslararası proje yarışmalarına katılacak projeler için kurumlar tarafindan hem yazım hem de sunum için yabanc1 dil desteği verilmelidir. 


\section{Extended Summary \\ Introduction}

Gifted students think critically by looking at problems from different perspectives and enjoy solving complex problems. They work diligently in areas of interest, prefer difficult tasks, and find practical solutions to problems through their strong intuition. They also spend most of their time dealing with projects. When these students are trained in line with their abilities, they will be able to contribute greatly to the improvement of societies in the future. Hence, societies that become aware of gifted students have considered the necessity of implementing an education program different from their peers by making necessary improvements for these students.

Science and Art Centers are the leading institutions which have been opened for the education of gifted students in our country and they continue their activities today. Project studies are carried out intensively in these institutions, because the project work has many benefits. It is important that gifted students, who devote most of their time to finding solutions to problems and to project study, do their project work more systemically in Science and Art Centers.

Many problems may arise in project work. For example, students have problems in accessing materials and data collection tools. They are inadequate in writing the project report and presenting the project. In addition, students have problems in the creation of the project idea and task sharing. It is important to identify these problems. In this context, it is necessary to determine the opinions of the gifted students who are personally involved in the project work.

As a result of all these evaluations, the aim was to investigate the students' opinions about the project work carried out in the Science and Art Centers. It is thought that the findings of this study will help students who want to do project work, teachers who work as project consultants and researchers who will work in this field. As a result, the question "What are the students' views on the project works carried out in the Science and Art Centers?" was investigated.

\section{Method}

In this study, a phenomenological design, which is one of the qualitative research method designs, was used. The study group of the research consists of five students studying at a Science and Art Center in the Eastern Anatolia Region during the 2018-2019 academic year and participating in project studies. A semi-structured interview was used as the data collection tool. In the preparation of the semi-structured interview form, firstly the literature was examined and a semi-structured interview form consisting of 12 items was created. In addition, a series of studies were conducted to control the factors that threaten the validity and reliability of the study and content analysis was used in the analysis of the data.

\section{Findings}

When the talented students were asked about the benefits of the project work they were assigned to, they stated that they have improved their decision-making ability, increased self-confidence, gained scientific research skills, and increased their problem-solving skills and cooperation. In addition, when asked about the effect of the activities carried out on the adequacy of the project, most of the participants stated that it was at a sufficient level.

It was stated by all the participants that the teachers, families and friends of the counsellors supported the project activities in many respects. However, some of the participants stated that they had problems in determining the project subject. Participants who had problems in determining the subject of the project stated that they had time problems in determining the subject. In addition, most of the participants stated that they had problems in terms of access to the data collection tool and material supplies during the project competitions.

\section{Discussion and Conclusions}

When the gifted students were asked about the benefits of the project work, they stated that the project work had many benefits. This result is similar to many studies. Project studies are an effective learning model that develop and test students' understanding levels in various educational activities. Therefore, it is important that gifted students drew attention to the stated benefits of the project work, which supports the idea of the students' awareness of the benefits of the project work.

Some of the participants stated that they had problems in determining the project subject. It is important to identify the problem and determine the subject to be studied so that students can produce solutions to current world 
problems. At this point, it is especially important that teachers help the students to find the idea of the project and show the necessary support.

Most of the participants stated that they had problems with the jury members in the project competitions in which they participated. During the completion of the projects, the project report should be prepared and oral and poster presentations about the project should be made. From this point of view, the behavior of the jury members is important. At this point, the participants suggested that jury members should be selected from a wide range of people interested in the project and that the jury members should concentrate on project presentations only on the day of the project. Most of the participants stated that they had problems in accessing the data collection tool and material supplies during the project studies. Different materials need to be used in order for successful and original projects to emerge and it is important that the school administration, universities and other institutions support the projects. As a result, it is recommended that gifted students studying at the Science and Art Center should be supported to carry out more successful project studies and more attention should be paid to project studies in these institutions. 


\section{Kaynakça / References}

Abu, N. K. (2018). Üstün yetenekli öğrencilerin kaynaştırılmasına yönelik farklllaştırllmış fen etkinliklerinin değerlendirilmesi (Yayınlanmamış doktora tezi). Amasya Üniversitesi, Amasya.

Ay, Ş. (2013). Öğretmen adaylarının proje tabanlı öğrenme ve geleneksel öğretime ilişkin görüşleri. Hacettepe Üniversitesi Eğitim Fakültesi Dergisi, 28(1), 53-67.

Aydın, M., \& Çepni, S. (2011). Fen ve teknoloji öğretmenleri için geliştirilen proje tabanlı öğretim yöntemi (PTÖY) konulu bir destek programının öğretmenlerin ihtiyaçlarını giderme durumlarının incelenmesi. Türk Fen Eğitimi Dergisi, 8, 55-68.

Ayvacı, H. Ş., \& Çoruhlu, T. (2010). Fen ve teknoloji dersi proje tabanlı öğretim uygulamasında ilköğretim öğrencilerinin karşılaştıkları güçlükler. Uludă̆ Eğitim Fakültesi Dergisi, 23(1), 43-59.

Baki, A., \& Bütüner, S. Ö. (2009). Kırsal kesimdeki bir ilköğretim okulunda proje yürütme sürecinden yansımalar. Illköğretim Online, 8(1). 146-158.

Baykoç, N. (2014). Üstün akıl, zekâ, deha, yetenek, dâhiler-savantların gelişimleri ve eğitimleri. Ankara: Vize Basın Yayın.

Bell, S. (2010). Project-based learning for the 21st century: Skills for the future. Clear House, 83, 39-43.

Büyüköztürk, Ş., Kılıç-Çakmak, E. K., Akgün, Ö. E., Karadeniz, Ş., \& Demirel, F. (2012). Bilimsel araştırma yöntemleri. Ankara: Pegem.

Cappelleri, D. J., \& Vitoroulis, N. (2013). The robotic decathlon: Project-based learning labs and curriculum design for an introductory robotics course. IEEE Transactions on Education, 56(1), 73-81.

Chandrasekaran, S., Stojcevski, A., Littlefair, G., \& Joordens, M. (2012). Learning through projects in engineering education. In the proceedings of SEFI2012: Engineering Education 2020: Meet the Future: Proceedings of 40th SEFI Annual Conference, Thessaloniki, Greece, 23-26.

Clark, B. (2013). Growing up gifted. Cambridge: Pearson.

Corbin, J., \& Strauss, A. (2007). Basics of qualitative research: Techniques and procedures for developing grounded theory. Thousand Oaks, CA: Sage.

Creswell, J. W. (2013). Nitel araş̧tırma yöntemleri: Beş yaklaşıma göre nitel araştırma ve araştırma deseni (Çev. Ed.: M. Bütün \& S. B. Metin). Ankara: Siyasal Yayncılık.

Çepni, S. (2010). Araştırma ve proje çalışmalarına giriş (5. baskı). Trabzon: Celepler Matbaacılık.

Çetin, O., \& Şengezer, B. (2013). Ortaokul öğrencilerinin proje çalışmalarına ilişkin görüşleri. Ege Eğitim Dergisi, 14(1), 24-49.

Demirhan, E. (2018). Opinions of gifted students and prospective teachers on nature education program based on mentoring approach. Inonu University Journal of the Faculty of Education, 19(3), 175-188.

Erdoğan, İ. (2018). Üstün yetenekli öğrencilerin bilimsel araştırma becerilerinin öğrencilerin yaptığı araşttrmalara dayalı olarak incelenmesi (Yayınlanmamış yüksek lisans tezi). Necmettin Erbakan Üniversitesi, Konya.

Giorgi, A. (2009). The descriptive phenomenological method in psychology: A modified Husserlian approach. Pittsburg, PA: Duquesne University.

Gökdere, M., \& Ayvacı, H. Ş. (2004). Determination of primary teacher's knowledge level about giftedness concept. Ondokuz Mayls Üniversitesi Eğitim Fakültesi Dergisi, 18, 17-26.

Gültekin, Z. (2009). Fen eğitiminde proje tabanl öğrenme uygulamalarının öğrencilerin bilimin doğaslyla ilgili görüsllerine, bilimsel süreç becerilerine ve tutumlarına etkisi (Yayınlanmamış yüksek lisans tezi). Marmara Üniversitesi, İstanbul.

Hart, J. (2019). Interdisciplinary project-based learning as a means of developing employability skills in undergraduate science degree programs. Journal of Teaching and Learning for Graduate Employability, 10(2), 50-66.

İdin, Ş., \& Özdemir-Şimşek, P. (2016). Proje tabanlı öğrenme kapsamında gerçekleştirilen ders dışı egzersiz çalışmalarına ilişkin öğrenci görüşleri. Illköğretim Online, 15(3), 761-777. 
Johnsen, S. K., \& Goree, K. (2009). Independent study for gifted learners (Original work published 2005). Agency-One, Seoul: Academy Press.

Johnsen, S. K. (2004). Definitions, models, and characteristics of gifted students. In S. K. Johnsen (Ed.). Identifying gifted/talented students: A practical guide (pp. 1-21). Waco, TX: Prufrock Press.

Kaya, F. (2019). Yorumsamacı yaklaşımda anlama kavramının önemi ve pozitivizm eleştirisi. Dicle Üniversitesi Sosyal Bilimler Enstitüsü Dergisi, 11(22), 271-280.

Kılıç, İ., \& Özel, M. (2015). Proje tabanlı öğrenme yönteminin fen ve teknoloji derslerinde uygulamaları hakkında öğretmen ve veli görüşlerinin incelenmesi. Sakarya University Journal of Education, 5(2), 7-20.

Lam, S. F., Cheng, R. W., \& Choy, H. C. (2010). School support and teacher motivation to implement project-based learning. Learning and Instruction, 20, 487-497.

Levent, F. (2014). Üstün yetenekli çocukları anlamak. Ankara: Nobel Yayıncılık.

Liu, Y., Lou, S., Shih, R., Meng, H., \& Lee, C. (2010). A case study of online project-based learning: The beer king project. International Journal of Technology in Teaching and Learning, 6(1), 43-57.

MEB. (2015). Millî Ĕ̆itim Bakanlı̆̆ı Bilim ve Sanat Merkezleri Yönergesi. Erişim adresi: https://orgm.meb.gov.tr/meb_iys_dosyalar/2016_10/07031350_bilsem_yonergesi.pdf

MEB. (2017). 2017-2018 Bilim ve Sanat Merkezleri Öğrenci Tanılama Kılavuzu. Erişim adresi: https://orgm.meb.gov.tr/meb_iys_dosyalar/2017_10/28150742_2017-2018_bilsem_tanilama_kilavuzu.pdf

Mills, P. (2003). Group project work with undergraduate veterinary science students. Assessment \& Evaluation in Higher Education, 28(5), 527-538.

Mioduser, D., \& Betzer, N. (2007). The contribution of project-based learning to high achievers' acquisition of technological knowledge and skills. International Journal of Technology and Design Education, 18(1), 59-77.

Ocak, M. A., \& Ulusoy, Ç. (2010). Investigation of college students' intrinsicmotivation in project based learning. International Journal of Human Sciences, 7(1), 1152-1169.

Orbay, M., Gokdere, M., Tereci, H., \& Aydin, M. (2010). Attitudes of gifted students towards science depending on some variables: A Turkish sample. Scientific Research and Essays, 5(7), 693-699.

Özarslan, M. (2015). Proje paydaşlarının BİLSEM biyoloji projeleri hakkındaki düşünceleri ve bu projelerin üstün zekalı ve yetenekli ögrencilerin biyoloji ögrenmeye yönelik motivasyonları ile bilimsel tutumlarına etkisi (Yayınlanmamış doktora tezi). Balıkesir Üniversitesi, Balıkesir.

Özarslan, M. (2019). Üstün zekâlı ve yetenekli olan ve üstün zekâlı ve yetenekli olmayan öğrencilerin biyolojiye ilişkin algılarının karşılaştırılması: Metaforik çalışma. Pamukkale Üniversitesi Ĕ̆itim Fakültesi Dergisi, 45, 310-334.

Özarslan, M., \& Çetin, G. (2015). Üstün zekâlı ve yetenekli öğrencilerin biyoloji proje çalışmalarına ilişkin görüş ve beklentileri. Üstün Yetenekliler Ĕgitimi Araştırmaları Dergisi, 3(2), 58-83.

Özarslan, M., \& Çetin, G. (2018). Üstün zekâlı ve yetenekli öğrencilerin biyoloji proje çalışmalarına ilişkin görüş ve beklentileri. Üstün Yetenekliler Ĕgitimi Araştırmaları Dergisi, 3(2), 58-83.

Özarslan, M., Çetin, G., \& Yıldırım, O. (2017). Üstün zekâlı ve yetenekli öğrenci ailelerinin bilsem biyoloji proje çalışmaları hakkındaki görüşleri. Abant İzzet Baysal Üniversitesi Eğitim Fakültesi Dergisi, 17(3), 1411-1436.

Öztuna-Kaplan, A., \& Diker-Coşkun, Y. (2012). Proje tabanlı öğretim uygulamalarında karşılaşılan güçlükler ve çözüm önerilerine yönelik bir eylem araştırması. Mersin Üniversitesi Ĕgitim Fakültesi Dergisi, 8(1), 137-159.

Powers, E. A. (2008). The use of independent study as a viable differentiation technique for gifted learners in the regular classroom. Gifted Child Today, 31(3), 57-65. 
Raghavan, K., Coken-Regev, S., \& Strobel, S. A. (2001). Student outcomes in a local systemic change project. School Science and Mathematics, 101, 268-281.

Rajan, K. P., Gopanna, A., \& Thomas, S. P. (2019). A project based learning (pbl) approach involving pet recycling in chemical engineering education. Recycling, 4(10), 1-16.

Renzulli, J. S. (1986). The treering conception of giftedness: A developmental model for creative productivity. Conception of giftedness. Cambridge: Press syndicate of the University of Cambridge.

Sarı, H., \& Öğülmüş, K. (2014). Evaluation of the problems faced by teachers and students in science and art centers. Uluslararası Türk Eğitim Bilimleri Dergisi, 2(2), 254-265.

Sarıtaş, E., Şahin, Ü., \& Çatalbaş, G. (2019). Velilerin gözüyle BİLSEM. Eğitimde Nitel Araştırmalar Dergisi, 7(1), $114-133$.

Sezginsoy, B. (2007). Bilim ve sanat merkezi uygulamasının değerlendirilmesi (Yayınlanmamış yüksek lisans tezi). Balıkesir Üniversitesi, Balıkesir.

Stuart, T., \& Beste, A. (2011). Farklı olduğumu biliyordum: Üstün yeteneklileri anlayabilmek (Çev: A. Gönenli). Ankara: Kök Yayıncilik.

Summers, E. J., \& Dickinson, G. (2012). A longitudinal investigation of project-based instruction and student achievement in high school social studies. Interdisciplinary Journal of Problem-Based Learning, 6(1), 82-103.

Tischler, K., \& Vialle, W. J. (2009). Gifted students' perceptions of the characteristics of effective teachers. In D. Wood (Ed.), The gifted challenge: Challenging the gifted (pp. 115-124). Merrylands, Australia: NSWAGTC Inc.

Tortop, H. S. (2013). Bu benim eserim bilim şenliğinin yönetici, öğretmen ve öğrenci görüşleri ve fen projelerinin kalitesi odağından görünümü. Adlyaman Üniversitesi Sosyal Bilimler Enstitüsü Dergisi, 6(11), 255-308.

Ülger, B. B. (2011). Bilim sanat merkezlerinde uygulanan fen ĕgitimi programlarının idareci, ögretmen ve ögrenci bakış açısından incelenmesi (Yayınlanmamış yüksek lisans tezi). Çukurova Üniversitesi, Adana.

Yıldırım, A., \& Şimşek, H. (2013). Sosyal bilimlerde nitel araştırma yöntemleri (9. baskı). Ankara: Seçkin Yayıncılık. 